\title{
四 \\ The Solution to the Financial Literacy Problem: What is the Answer?
}

\author{
Sharon Taylor ${ }^{1} \&$ Suzanne Wagland
}

\begin{abstract}
Over the last two decades the need for a financially literate population has grown in importance. Hence in Australia, it is imperative that individuals possess both the financial knowledge and capability to make sound financial decisions. In contrast, the results of the Australian \& New Zealand Bank (ANZ) surveys from 2003 to 2010 have demonstrated that there is a substantial deficiency in the level of financial literacy amongst many of the Australian population.

Both the government and the private sector have encouraged the development of financial education programs as an important tool in remedying the detected low levels of financial literacy as reported in the ANZ research. The Australian Security and Investment Commission (ASIC), the government regulator, has strongly promoted the need to develop confident and informed consumers and investors through the provision of quality financial education. ASIC's focus was reiterated in its Report 229, the National Financial Literacy Strategy. This report which was announced in March 2011 set out the strategy for the development and delivery of initiatives to improve financial literacy levels in Australia (ASIC 2011).

In particular, the National Strategy has been developed to improve the level of financial literacy among Australian students. The focus is on incorporating financial education through the existing school curriculum, beginning in kindergarten through to year 12 students.

The aim of this research paper is to challenge and ask questions relating to the Australian Government's financial literacy strategy directed at schools. This direction would appear to have limited support of success, given the evidence published in the USA, and to a limited extent in the United Kingdom and Europe. This study reviews the current evidence available in both Australia and the USA in relation to financial literacy projects in schools. In respect of the international experience this paper explores the possible reasons for their limited success, and in some cases failure, to deliver the desired outcomes.

In Australia there has been no academic research as to the possible effectiveness of teaching financial literacy at a school level. Given the USA research into such initiatives, this paper seeks to question the policy direction of the government in Australia. This paper also challenges the validity of the current Australian approach. The emphasis placed upon school financial literacy programs defies the wealth of evidence overseas which has failed to identify any measurable improvement in financial knowledge, attitudes and behaviour as a result of imbedding financial literacy in school education curriculum.
\end{abstract}

Keywords: Financial literacy; ageing population; government policy; education.

JEL classification: D12, I21, I22, I28.

1 University of Western Sydney

Email:sharon.taylor@uws.edu.au 


\section{Introduction}

A review of the Australian Government initiatives and policies undertaken by Taylor and Wagland (2011) describes the financial environment over the last two decades. In their paper Taylor et al stated, that the financial services industry has grown exponentially over the last two decades providing numerous services and products. As a consequence, the everyday basics of saving, obtaining the right mortgage and an investment strategy for the future requires a degree of financial skill. In Australia, the additional introduction of compulsory superannuation has resulted in further services and products focusing on retirement. This environment necessitates the importance of personal financial literacy to empower individuals to successfully navigate the current financial services industry

In today's world of increasingly complex financial decisions, "financial literacy may be considered a vital skill for all consumers" (ASIC 2003). A review of the literature indicates there are several definitions when it comes to financial literacy. Schagen and Lines (1996) define financial literacy as "the ability to make informed judgments and to take effective decisions regarding the use and management of money" (Schagen \& Lines 1996, p91). The definition adopted by ASIC conforms to the definition proposed by Schagen and Lines (1996) and further elaborates by detailing the following skills and knowledge as constituting financial literacy:

- mathematical literacy and standard literacy (the ability to read for knowledge

and write coherently and think critically about the written word)

-financial understanding - an understanding of what money is and how it is exchanged, where it comes from and goes

-financial competence - understanding of basic financial services, financial records (and importance of reading and keeping them), attitudes to spending and saving, and an awareness of the risks associated with some financial products and the relationship between risk and return; and

-financial responsibility - the ability to make appropriate personal life choices about financial issues, understanding consumer rights and responsibilities and

-the ability and confidence to access assistance when things go wrong.

Many organisations including the Australian Financial Literacy Foundation, ANZ Bank and the New Zealand Retirement Commission have utilised a similar definition to that of Schagen and Lines (1996). Broadly, this definition of financial literacy incorporates the understanding of money, and the ability to make effective and beneficial personal financial decisions. To achieve this objective individuals require an understanding of financial terms and concepts, as well as the ability to use technology, some understanding of the availability of credit and investment markets generally (Reid 2003).

The definition used in this research paper predominantly agrees with the ASIC definition in relation to financial literacy. Additionally this study uses the terms financial literacy or financial capability as interchangeable.

If individuals are to navigate the current financial landscape, there is an increasing need for financial knowledge and at minimum, basic financial skills (Morris 2001). Financial literacy has major implications for the welfare of individuals, in the management of their financial affairs and financial stability. Anecdotal evidence suggests that a financially educated society allows individuals to better make financial decisions. These decisions relate to budgeting, spending and saving habits, as well as an attitude to the benefits of investing. Additionally, individuals will need to assess the best way to borrow money and how to manage financial risk and most importantly to be more aware of scams. With the increasing diversity and complexity of financial services and products worldwide, which includes debt instruments, investment products along with general public offers, individuals are presented 
with greater choice and opportunities than ever before. However, this environment potentially increases the risk for the individual to make a poor decision. To reduce the risk of poor decision making (Widdowson \& Hailwood 2007) financial education and awareness becomes pivotal.

The aim of this research paper is to compare the government's financial literacy strategy in schools in Australia to that undertaken in the USA and to a limited extent in Europe. This exploratory paper is the second in a series looking at government policy and initiatives related to financial literacy. This study describes the current state of play in both Australia and the USA in relation to financial literacy projects in schools. In respect of the international experience the paper explores the possible reasons for their limited success and in some cases failure to deliver the desired outcomes.

In Australia there has been no academic research as to the possible effectiveness of teaching financial literacy in schools and given the USA experience, this paper seeks to justify why the Australian Government would be so dedicated to this initiative. This research reviews the Australian government's policy relating to teaching financial literacy in schools and seeks to find evidence to support this direction. The substantial evidence from the USA is reviewed as are the results of surveys undertaken evaluating such programs. This paper goes on to comment on the apparent dichotomy as to solution to the financial literacy problem between the Australian approach and the evidence from overseas.

\section{Literature Review}

There is no doubt that financial services products in the 21st century are increasingly complex. This environment heightens the need for a financially literate community if individuals are to navigate the financial services landscape. Current low levels of financial literacy are seen as contributing to the problem of poor mortgage choices and unsustainable high levels of debt (Mandell 2009). Logically there is the argument that personal finance should be part of basic education of all students (Mandell 2008; 2009), and most developed nations have adopted or aim to mandate financial education as part of the kindergarten-year 12 curriculum (OECD 2005).

Although incorporating financial education through the school curriculum seems a logical response, the research findings about the effectiveness of financial education are mixed. Bell and Lerman (2005), Braunstein and Welch (2002), Fox, Bartholomae and Lee (2005), Hilgert, Hogarth and Beverly (2003), Hogarth (2002), Hogarth, Beverly and Hilgert (2003), Lyons (2005), and Lyons et al. (2006) in their research suggest that financial education results in positive behaviour change. Additional research that has focused on youth and financial literacy education has also provided evidence that formal courses in personal finance can increase financial knowledge, and often result in more positive financial behaviour (Jump\$tart Coalition 2011). Research by Boyce and Danes (2004) suggests formal financial literacy programs provide a significant and positive impact on high school students' spending habits. Bernheim, Garrett and Maki (2001) found that financial education during high school resulted in higher savings rates. Staten, Elliehausen, and Lindquist (2002) findings support the previous studies in that their results indicated that individuals who received credit counselling were able to reduce their debt and improve their credit card management. In summary, the research provides evidence that financial education can improve the financial well-being of individuals and their families. Many of these studies focused on low-income populations and have relied on data collected solely from program participants.

Not all research though is positive. Some researchers and financial professionals question whether the amount of financial education matters. Clancy, Grinstein-Weiss and 
Schreiner (2001) and Schreiner, Clancy and Sherraden(2002) suggest that a few hours of general financial education increases savings, although the effects may diminish or reverse as time elapses. Research undertaken by de Meza, Irlenbusch and Reyneirs (2008) argues that financial education is likely to have a modest impact. Their research also suggests that it is difficult to change deep seated psychological traits using any form of conventional knowledge based education.

The Jump\$tart Coalition for Personal Financial Literacy which is a USA organisation, is recognised as one of the most widely referenced resources in understanding what young people know about personal finance. They have conducted both biennial and national surveys measuring the financial literacy of high school seniors since 1997. Although survey results have indicated poor levels of financial literacy, the 2008 survey showed students had the lowest score of any survey issued to date, with high school seniors answering just 48.3 percent of the financial literacy questions correctly. Kozup and Hogarth (2008) argue that there is no one solution to the financial literacy problem. They suggest that although worthwhile, financial education programs start with a participant-defined goal with students ranging from kindergarten to year 12. They concluded that behavioural changes will depend on an individual's determined goals not based on a participant-defined goal. This theory is now supported by the Jumpstart Coalition research, which suggests that financial literacy programs might be wasted on those who are too young to grasp key concepts. The coalition research indicates that teenagers aren't interested in, or are not capable of, taking money management issues seriously until they are in their late teens and early twenties. Concepts such as income tax, insurance, the economy and investments are difficult for young teenagers to absorb, because most of the subject matter is abstract and lacking in immediate relevance (The Financial Brand 2010).

Other studies indicate that perception may influence outcomes. Research undertaken in 2009, at the Investor Education Foundation (FINRA) suggest that low levels of financial literacy amongst Americans may be explained by the fact that Americans think they are more financially savvy than they really are. The research indicated that people's self-perceptions differed significantly from their actual banking behaviour (FINRA Investor Education Foundation 2009).

This literature review establishes that overseas research results indicate minimal improvement through the use of school financial literacy strategies, which begs the question why Australia has continued with this approach as its prime response to the financial literacy problem. Appendix A provides a comparative table of the surveys and reports that have been undertaken in relation to financial literacy in Australia, USA and UK.

\section{The Australian Experience}

\section{Financial Literacy in the General Australian Population}

Australia's first national survey on adult financial literacy was conducted by Roy Morgan Research on behalf of the Australian and New Zealand Bank (ANZ) in 2003 and repeated in November 2005 and again in October, 2008. The survey results indicated that most people are reasonably skilled at managing their daily finances but were not able to manage more complex issues. Most understand that higher returns mean higher risks, but many are susceptible to misleading claims. Whilst consumers generally understand their bank account/credit card fees and charges, far fewer understand fees, charges and statements for managed investments and superannuation (ANZ 2003). Findings by Beal and Delpachitra (2003) further support the poor state of financial knowledge of the Australian community about the government mandated superannuation system. Their research was conducted 
amongst a higher educated, higher-wealth, mainly professional and managerial group of participants and surprisingly resulted in only twenty two per cent of respondents able to score a fifty percent pass rate when questioned about the government mandated superannuation system.

In addition to high debt levels, increased bankruptcies and poor preparation for retirement, ASIC indicated that consumers had lost over $\$ 800$ million in the three years from 2000 to 2003 through scams and misleading prospectuses (ASIC 2003). In addition, Reid (2003) states that Citigroup research shows approximately 900,000 families are under financial stress. These indicators highlight the fact that many Australians are susceptible to misleading information and have failed to manage their finances responsibly. Consequently, the need for individuals to be more knowledgeable about money matters and to increase their skills to make beneficial financial decisions is critical (ASIC 2003; Giskes 2005; The Consumer and Financial Literacy Taskforce 2004).

\section{Financial Literacy in Schools}

In June 2003, ASIC published their Consultation Report 45, relating to financial literacy in schools. This report was the result of a study commissioned by ASIC to identify the current status of financial literacy education in Australian secondary schools and involved a curriculum map revealing opportunities for teaching financial literacy and a survey of available resources to support the teaching of financial literacy skills. In addition the report outlined the nature of financial literacy education in schools overseas (the UK, the USA and New Zealand) and highlighted any lessons that could be learnt from their experiences. The report goes on to recognise that an adequate level of financial literacy will only be achieved with the combined efforts of a number of sectors and organisations working together.

It was acknowledged in the report that financial literacy to a limited extent was already being taught in the school curriculum. First, school curriculum had been reviewed nationally to ensure the inclusion of financial literacy in identified subjects. This curriculum coverage was included in non-compulsory units hence not all students would be exposed to these important financial concepts. A holistic approach to financial literacy curriculi was not undertaken, so some students undertook subjects which did not include financial literacy topics. Secondly, school banking had been an established part of the school environment for many years in Australia which gave students an awareness and opportunity to engage with savings accounts and hence concepts of interest and earnings. These programs were usually sponsored by the Commonwealth Bank.

The goal of ASIC as stated in its report is:

“(a) see every student leaving school with the necessary basic skills in financial matters to become confident and informed consumers in their work and personal life;

(b) help education jurisdictions across Australia enhance and build on existing financial literacy educational programs in schools, with a particular focus on Years 8, 9 and 10 ;

(c) see a variety of up-to-date, relevant and stimulating teacher resources to support the teaching of financial literacy;

(d) develop a coordinated approach to the supply and sharing of information on financial literacy for teachers across Australia; and

(e) promote teacher training and professional development courses to support the effective teaching of financial literacy.” (ASIC 2003, p15).

The results of the ASIC study indicated that of the thirty schools interviewed, few schools had any idea of how financially literate their students really were and none had made any formal evaluation of the extent to which any of their efforts had been successful. Not 
only are there no measures of financial literacy within curriculi, but there had not been any benchmark tests of the financial literacy levels of Australian school students. The report confirms that an evaluation in the form of testing will be required to evaluate the success of any future initiative undertaken. To date no such evaluation has been published and announcements relating to a possible tender for testing within schools has not been forthcoming to date.

\section{Financial Literacy Resources for School}

ASIC understood the need for collaboration to provide the necessary resources to schools if any such programs were to be successful. Whilst ASIC was developing new resources they acknowledged that the financial services industry had already developed materials that were readily usable in the classroom. An example was the Financial Planning Association's Dollar\$mart CD-ROM. ASIC was keen to tap into the many existing resources however, they soon found that many of these were rapidly becoming out of date or were no longer available in hard copy. There was a hope that, once work on a proper framework commences, financial industry associations and individual financial institutions will be willing to invest more money into developing financial literacy resources. To date there is no evidence that any substantial support has been forthcoming. Whilst limited resources have been developed many are only available through websites and are marketed to the public directly. Some schools' specific resources have been developed over the last decade however, they have been used in specific school locations and no evaluations of their successfulness have been undertaken.

\section{ANZ 2003 Financial Literacy Study}

In 2003, the ANZ conducted the first financial literacy study in Australia. The study states that:

"The purpose of the survey was to identify: benchmarks for the ongoing measurement of financial literacy across the entire adult population; any segments of the population that have low levels of financial literacy; and aspects of financial skills, products and services that are causing the greatest problems for consumers" (ANZ 2003)

The telephone survey was completed by 3,548 adult Australians, and was comprised of 145 finance and 25 demographic questions. Additionally, stage 3 of the study involved an in-depth survey of 202 people including a self-completion component and in-depth interview of 1-1.5 hours each.

The results of the study also identified the groups that displayed the greatest challenges in making financial decisions. The lowest levels of financial literacy were associated with those having low education qualification (Year 10 or less), those categorised as unskilled workers, as well as respondents with less than $\$ 20000$ in household income. Additionally, those with low savings, single people and people at both extremes of the age profile (18-24years old and over 70 years).

\section{Australian Financial Literacy Foundation and the Young}

In a response to the ANZ Bank survey 2003, the Australian Government in 2005 established The Financial Literacy Foundation (FLF). Over the years the foundation operated there was a strong emphasis on training teachers and their focus was dedicated mostly to introducing financial literacy as part of the education curriculum kindergarten to year 12. The FLF 
undertook surveys to determine teachers' competencies in financial literacy and developed program to overcome the deficiencies identified.

\section{5 /2008 ANZ Studies and the Young Identified at Risk}

The 2005 ANZ study concluded that while the overall results confirm the Australian community is financially literate when it comes to looking after their daily financial decisions, there are certain groups that still have particular challenges. The groups with the lowest levels of financial literacy were the same as indicated in the 2003 study.

Additionally in 2008 ANZ conducted a similar survey to the 2003 and 2005 surveys and found that overall the lowest levels of financial literacy had remained unchanged.

\section{8 and ASIC Becomes Responsible for Financial Literacy Strategies}

In 2008 the Federal Treasurer Wayne Swan, announced that as part of the Rudd Government's agenda regarding ongoing efforts to improve financial literacy, the functions which were previously the responsibilities of the FLF were to be transferred to the ASIC from 1 July 2008. To achieve this desirable outcome ASIC embarked on a campaign to teach the teacher in 2008 and 2009. This program was supported by a teacher and educator resource website which provided additional materials for use in the classroom.

In Australia, as early as 2003, ASIC had published a discussion paper relating to financial literacy in schools. ASIC's direction to improve financial literacy has remained unchanged. ASIC has been consistent in implementing policy directed at increasing financial literacy levels through educating the young. Hence, the current policy continues to promote financial education initiatives through incorporation of content into the school curriculum (ASIC 2003).

The Australian Association of Mathematics Teachers Inc (AAMT) position paper indicates that students' financial literacy should be built through integrating knowledge and skills from a wide range of learning areas (AAMT 2009). The AAMT in their report state that the financial literacy requires a number of skills. First, a broad knowledge not only of financial concepts but knowledge of what money is for and how it is used (Humanities and Social Sciences). Secondly, written, mental, calculator and computer skills in calculating with money (Mathematics; Information and Communication Technology) combined with an understanding of the "fine print" (English). Thirdly, the report highlights the need to manage oneself and ensure personal well-being (Health and Physical Education), as well as an understanding of sustainability issues and the "costs" associated with resource use (Sciences; Environmental Sustainability). Finally, students need to have skills as mentioned, tempered with awareness or a sense of ethical behaviour (Civics and Citizenship) (AAMT2009).

It would seem to logically flow from this report that financial literacy curriculi needs to be embedded in a variety of subjects especially mathematics. Given that many students cease to study mathematics after Year 10 that this would be the appropriate time to quantify through testing the level of financial literacy achieved by each student. Once this data is available possible alternative enhancement programs could be developed and implemented.

\section{National Financial Literacy Strategy}

In March 2011, ASIC released Report 229, the National Financial Literacy Strategy. The strategy emphasises the importance of education and recognises the concept of lifelong learning and education generally as central to the strategy. In Australia education pathways 
begin in early childhood, school education, further education (this includes vocational and tertiary education) and finally adult and community education. ASIC in this report emphasises that financial literacy in schools is particularly important and plays a pivotal role in the national strategy. The report highlights more than ever that students need vital skills upon leaving school. These skills include:

- “Equipped for life’s financial decisions

- More attuned to their own consumer behaviour

- Knowing the questions to ask and make smarter financial decisions and

- Armed with knowledge and skills to be able to secure and improve their financial wellbeing."(ASIC 2011, p18)

An essential part of the strategy is to ensure an integrated framework within the school curriculum across such areas as English, Mathematics, Science, Humanities, Civics and Information and Communication technology. The report states that the following key elements need to be covered in the framework:

- "Understanding money ( the focus for lower primary)

- Consumer literacy ( upper primary)

- Personal finance ( lower secondary)

- Money management ( upper secondary)” (ASIC 2011, p19)

The Australian Government as part of its education reform agenda has recently developed a new Australian Curriculum to be phased in from 2011-2013. ASIC has stated that as part of this reform agenda it wishes to ensure that financial literacy skills are both "integrated and embedded" in the new curriculum. The current policy is espoused in Report 229: National Financial Literacy Strategy. Appendix B provides the Map of the National Financial Literacy Strategy as set out in Report 229. Column 1 relates to the strategy as it relates to education. ASIC states in the report:

- As part of the Government's education reform agenda, the Australian Curriculum is being developed and phased in from 2011-13. This curriculum will detail what teachers are expected to teach and what students are expected to learn for each year of schooling. It will support the attainment of the second goal articulated in the Melbourne Declaration on Educational Goals for Young Australians, to ensure that 'all young Australians become successful learners, confident and creative individuals, and active and informed citizens'.

- ASIC is committed to ensuring that consumer and financial literacy skills are integrated and embedded in the new curriculum. This is vital if we are to build on the progress made to date and equip our young people with the skills, knowledge and attributes to make responsible and informed consumer and financial decisions (ASIC 2011, p.20).

The Australian Government Financial Literacy Board (FLB) is a non-statutory body that provides advice to government and ASIC on financial literacy issues.ASIC, with the support of the FLB has actively discussed with government the inclusion of financial literacy in the new curriculum. ASIC continues to liaise with other stakeholders in schools as well as the teacher's professional associations. These associations have provided responses to the Australian Curriculum, Assessment and Reporting Authority (ACARA) on drafts of the proposed Mathematics, Science and English curricula. Their comments particularly relate to the mathematics curriculum, where it is intended to locate much of the money and financial mathematics content. This response supports the view of the AAMT expressed in their position paper in 2009. 
As part of this process ASIC acknowledges the importance of resourcing teachers with appropriate materials and continuing professional development. The Australian Government established the Financial Literacy Foundation (FLF) to give all Australians the opportunity to better manage their money: to raise awareness of financial literacy and its benefits; and create opportunities for Australians of all ages to learn more about money - at school, through vocational and higher education, in the workplace and in the community. The importance of teacher education as identified by the FLF in 2003 has not changed. Teachers and their knowledge base are the critical elements if this initiative is to be successful. Hence effective teaching is of paramount importance in the success of any financial literacy education programs. ASIC currently provide a teachers resource on their website and in addition Money\$mart has been developed as part of the overall financial literacy strategy.

ASIC has indicated that this approach will continue to be developed over the forthcoming years and anticipates that changes will progressively be made to the education curriculum. To ensure a robust approach ASIC has established a national reference group to provide strategic advice in relation to the school sector. In order to evaluate the success of this initiative ASIC intends to seek evidence through international comparisons by participating in the 2012 Program for International Student Assessment test. This program is currently on hold and ASIC have not committed to testing in 2013. Appendix C sets out in detail ASIC's financial literacy priorities for schools. To date there is no quantitative evidence as to the success of the school financial literacy program. In Australia, such programs have not been independently reviewed nor has an evaluation process been developed to determine the cost benefit feasibility of continuing this initiative. The most recent ASIC Report 230, Financial Literacy and Behavioural Change was published in March 2011. This report includes data gathered between 2008 and 2010 and summaries what ASIC and others have learned about financial literacy to date. The report states that although the financial literacy movement has gained momentum, there remains little reliable, conclusive research about whether financial literacy campaigns and programs work. Best-practice principles for program and evaluation techniques are still developing, and it is widely recognised that both are inherently difficult.

The USA experience reported by the Jump\$tart coalition studies, raises questions as to whether financial literacy as a part of the school curriculum is the best and most cost effective solution to the financial literacy problem. ASIC further contends that improving knowledge alone, however, will not be enough to achieve better financial outcomes for all Australian financial consumers and retail investors. ASIC acknowledges that financial literacy campaigns are only one response in the overall financial literacy strategy. The report accepts that other initiatives need to be considered. One such strategy might include looking to develop a generic advice/guidance service for the mass market. This would give Australians access to free, quality independent financial guidance and back-up aids to help them implement and stick to the financial plan.

It is interesting to note that in the 2011 ASIC report, the strategy of financial literacy education in schools barely rates a mention.

\section{United States of America Experience}

\section{Financial Literacy and Schools}

The most extensive research in respect of financial literacy in schools has been undertaken by the Jump\$tart coalition between 1997 and 2008. Whilst current financial literacy programs in schools in the USA have had little success the Jump\$tart Coalition surveys do provide some encouragement for future initiatives. It would appear from the results of the studies that 
generally the financial community has not yet figured out how to make young people financially capable. Although formal learning does not appear to result in desired financial literacy outcomes, there is some hope for non-cognitive and behavioural learning. The Jump\$tart coalition college survey shows that while a high school class in financial management has no impact on financial literacy, it does appear to have a positive impact on self-beneficial behaviour of college students. This implies that students are more likely to be receptive to behavioural change where they can see that it would immediately and directly benefit them personally.

The Jump\$tart coalition survey's results are supported by the research of Willis (2008) whose studies suggest that there are serious questions to be answered about the usefulness of mandating the teaching of financial literacy. Willis (2008, p208, 254) cites the Jump\$tart findings concluding that "the search for effective financial literacy education should be replaced by a search for policies more conducive to good consumer financial outcomes." In addition, recent studies confirm Willis's findings are supported by some behavioural economists who argue that information-based financial education is likely to have at best, a modest impact (de Meza et al. 2008).

\section{Possible Explanations for Poor Schools Program Outcomes}

Leading academics in the area, Mandell and Klein (2007) stated that even after taking a course in personal finance low financial literacy scores were recorded. Their study suggested a possible explanation for this was an apparent lack of motivation by students to both learn and retain these taught skills. This same study, which comments on the Jump\$tart coalition surveys, highlights that over five successive surveys 1997-2006, scores remain low despite the recent attention to the importance of financial literacy. This problem is not only seen in the USA. In 2005 the Organisation for Economic Co-operation and Development (OECD)found this lack of financial literacy was widespread affecting Australia, Japan, Korea and the US to name a few.

Mandell et al (2007), suggests that while lack of motivation may be a key factor, resulting in low financial literacy scores in the young, results of the study also suggest that financial knowledge is linked to financial practice. To support this statement the study draws attention to the Stock Market Game where participants in the games consistently demonstrate higher financial literacy scores than their peers. When students are exposed to a practical approach through such activities as the Stock Market Game, it appears this helps overcome the lack of motivation that would otherwise be evident.

A summary of the research in the USA over the past 15 years has provided some positive outcomes from a school-based financial education system (Mandell 2011). Initially student scores on the Jump\$tart national exam bounced by about $2 \%$. This was a result of having skilled and trained teachers, where students studied a semester-long course in personal finance (Mandell 2006). From a policy perspective, these findings would suggest that the mandated teaching of personal finance at the secondary level be strongly reconsidered. Before continuing in this direction, the Australian Government should seek solid evidence that this is an effective strategy and that the cost is affordable now and into the future based on the measurable outcomes.

\section{United Kingdom and European Experiences}

In the United Kingdom (UK), the Financial Services Authority (FSA) which existed between 2000-2010 was the government regulator responsible for the regulation of the financial services industry. In 2005-6, the FSA sponsored research into financial literacy among UK 
citizens. This encompassed an exploratory qualitative study measuring financial capability in the UK. As a result of the research findings, indicating low levels of financial literacy generally, in 2006 the FSA announced its strategy to deliver a specific set of projects to promote financial capability education for children and adults (FSA 2006).

The research by the FSA in 2005-6 was undertaken to investigate financial capability among UK population. The aim of the survey was to establish a baseline for financial capability focusing on five dimensions;

- the ability to manage money;

- keeping track of finances,

- planning ahead;

- choosing financial products and

- staying informed about financial matters.

This survey was the most comprehensive study of its kind comprising face-to-face interviews with a total of 5,328 people across the UK. The study's aim was to create a scoring mechanism to identify people's relative strengths and weaknesses in the financial capability domains. This report highlighted the concern that certain groups still displayed unsatisfactory levels of financial capability across all domains.

In each of the five dimensions, a number of questions were developed or adapted to gather information. A statistical approach was used to create a new measure, or score, based on the answers to a wide range of questions. The scores also took into account some differences in personal circumstances (Atkinson et el 2006). The study results found clear indications that individuals may be particularly capable in one or more areas, but lack skills and experience in others. There were some strong positive associations across the dimensions. For example, those people who scored highly for planning ahead also had high scores for making ends meet, staying informed and choosing products.

However, findings from the research did show that overall people were not particularly good at planning ahead, with fewer than half of the respondents interviewed having any provision for a loss in income or enough money to meet unexpected expenses. Of those surveyed eighteen percent admitted to signing contracts without reading them and some twenty two percent stated they did not stay informed about financial matters. The survey highlights that young people found it more difficult to balance their budget, especially those involved in renting, those who were unemployed, those households with children, and particularly single parents. The study results indicated that financial capability is lower where people are not forward-looking or who are either socially or financially excluded. On the other hand, capability is higher if people have been educated to A level (high school education 7 years) or above (Atkinson et el, 2006).

This survey from 2006 highlights the need for personal finance education to help the young. These programs should be directed towards the development of attributes in respect of knowledge and skills that they will require to manage their money effectively and to prepare for independent living. Following the 2006 survey, the FSA sponsored a survey of some 1000 schools across the UK to provide an insight into the current delivery of financial education. Some of the key findings indicated that most UK schools believe that personal finance education is important, but many do not deliver it because they feel the school curriculum is already stretched. For those schools that do teach personal finance education, lessons are generally infrequent and cover a narrow range of topics. The study indicated most schools do not have an assessment policy in place for this subject. Additionally, few teachers feel confident in delivering personal finance education, and most would like more support and resources to help them. 
These findings helped to provide the foundations for a clear objective for the integration of financial education across UK schools. The aim was to raise the profile and status of personal finance education in schools and provide information, guidance and training that will show schools and teachers how personal finance education can be taught effectively, while offering teachers practical support. A range of targets were developed for 2009-10. Some of these included, school children to be more financially confident and capable, with improved knowledge of personal finance matters. It was hoped that these programs would provide the skills to enable young adults to understand the need to take control of their money and assist them in becoming more capable and confident in dealing with financial matters.

Although some progress has been attributed to this initiative, the researchers of this study have been unable to identify any study undertaken to assess the outcomes. Hence no definitive statement can be made as to the success or failure of the financial literacy in schools initiative in the UK. A review of the literature has failed to provide evidence that any follow up studies were undertaken.

In June 2010, the Chancellor of the Exchequer, announced plans to abolish the FSA and separate its responsibilities between a number of new agencies and the Bank of England (Vina 2010). The financial capability division of the FSA is now known as the Money Advice Service (MAS). Since the MAS became responsible for financial education, there appears to have been no comprehensive research similar to the original 2006 survey to review the financial education in schools strategy However, the MAS does have a comprehensive web site providing information to both youth and adults. Their aim is to provide unbiased money advice to consumers. However, when it comes to financial literacy in schools the MAS has been silent (MAS 2011).

Whilst it appears that the financial literacy in schools initiative is no longer a priority for the MAS, there are a number of private independent organisations who provide web site information and teaching aids to assist schools teach personal finance to students. These resources are provided by such organisations such as the Personal Finance Education Group and the 'Make Money Make Sense'.

To summarise, in the UK at the present time, there seems to be a lack of clear government policy to integrate financial education in the school curriculum, and no additional teacher training or teaching resources appear to be on the agenda of the MAS. In fact it would appear that the UK financial literacy in schools initiative having not been evaluated is at best on hold.

\section{Summary of Findings}

As Mandell's research over many years points out, we as a global community need to determine how we create a financially literate society and if there is one right way. Mandell after studying financial literacy programs over many years has come to the conclusion that current methods don't work. A growing number of researchers and educators agree that a more radical approach is needed. They advocate starting financial education a lot earlier than high school, putting real money and spending decisions into kids' hands and talking openly about the emotions and social influences tied to how we spend.

Amid such a complicated landscape, some experts question whether there could ever be enough education to adequately prepare individuals for financial life. A better solution, these critics contend, is to reform the system. "What works is creating institutions that make it easy to do the right thing," says David Laibson, a Harvard economics professor who, like Mandell, has decided after years of research that education isn't a silver bullet (Kiviat 2010 p1). 
With the lack of independent evaluation of school programs in Australia and elsewhere, it is impossible to determine the success or failure of the financial literacy in school programs. As is apparent from the overseas experience combined with ASIC's own statements that financial literacy in schools is extremely expensive and resource intensive. Without measurable outcomes it is difficult to justify continuation of this approach.

It is almost irrefutable that financial literacy is 'a good thing', but does this mean that schools should be responsible for developing students' financial literacy? Improving financial literacy levels in our community is not, and cannot be, the responsibility of any one sector or organisation alone. It requires a whole community response with cross sectoral support. The attainment of financial literacy for most people is a cumulative, lifelong process, not an event tied to a particular course of study. While we would not argue that schools should have sole responsibility for developing students' financial literacy, we certainly see them as having an important role to play. Creating a financially literate community is a long-term agenda. Encouraging and facilitating the provision of financial services education in schools is one of the key projects identified in the ASIC Consumer Education Strategy.

The most recent ASIC report 230, Financial Literacy and Behavioural Change was published in March 2011. Whilst this report acknowledges that the financial literacy movement has gained momentum, there remains little reliable, conclusive research about whether financial literacy campaigns and programs work. Best-practice principles for program and evaluation techniques are still developing, and it is widely recognised that both are inherently difficult. ASIC contends that improving education alone, however, will not be enough to achieve better financial outcomes for all Australian financial consumers and retail investors. This report accepts that other initiatives need to be considered. It is interesting to note that in this most recent ASIC report the strategy of financial literacy education in schools barely rates a mention.

\section{Recommendations and Future Research}

In the absence of concrete evidence to the contrary the success of financial literacy programs in schools cannot be determined. ASIC itself admits that financial education in schools is only one of many possible strategies to solve the Australian financial literacy problem. The success of any initiative will largely depend on resources and government will. To date the government has been loud on rhetoric but inadequate in resourcing both development and evaluation of existing programs under the supervision of ASIC. Government has a vested interest to ensure that their population is financially literate given an ageing population and the need to shift expectations from government support in retirement to one of a self-funded system. In order to ensure that individuals become self-funded it is obvious that they need to possess the knowledge and skills to make informed financial decisions that will assist in building their long term wealth

So what options are available to government?

First, there is a need for a public media awareness campaign highlighting why financial literacy is essential. This type of campaign could highlight the benefits as well as the pitfalls of not having sufficient financial capability. Additionally, this is an opportunity to advertise websites and availability of recommended programs.

Second, it is acknowledged that schools play an important role in solving the financial literacy problem. However, given the ever increasing cost burden it would seem an appropriate time to stop and undertake a comprehensive study to measure the effectiveness of the school strategy before further public funds be committed. As previously discussed in this paper the importance of mathematics in the school curriculum should not be undervalued. Over the last decade the importance of mathematics in school curriculum has declined 
substantially. This is evidenced by the fact that students are no longer required to undertake a unit of mathematics for HSC examinations. A mathematics subject would provide the key platform upon which to build financial literacy. This could begin as early as the primary school years. Given that many students abandon mathematics at year 10 this would be the advisable point to test and evaluate their level of financial capability. This could be undertaken through a financial literacy test or competition or NAPLAN. The student could receive a competent (C) or not yet competent (NYC) achievement level. For those NYC a special online/blended program could be offered to support their learning and develop them to the identified desirable level. However motivation and immediacy may impinge on a student's willingness to absorb and demonstrate the required skills.

This approach would only represent one piece of the solution. The foundation skills and knowledge obtained at school could be further developed upon joining the workforce. In the workplace, financial literacy could form part of induction and professional development programs. Upon joining the workforce many employees are faced with a variety of decisions relating to salary sacrifice, superannuation, insurance and other financial products. These sessions could be run by product providers as well as independent educators to address these products and strategies for wealth creation.

Third, products could to be simplified by the providers to reduce complexity. Much of the existing research recommends the drive to "plain english products" eg the MY Super initiative. This would remove the need for high levels of financial literacy and simplify the decision making process. In relation to seniors, that is those over fifty years of age, specialist knowledge and programs are required for retirement planning. These programs could be provided by organisations in the community sector as well as providers of products, for example, APIA.

It is the view of the researchers that there is no one solution to this problem. It must be accepted that financial literacy is a lifelong learning activity. Individuals' needs change over a lifetime and the level of financial literacy needs to change and develop to meet the continuing complexity of their financial environment and decision making. Many stakeholders have a role to play if a successful outcome is to be achieved, including government, schools, employers, product providers and community organisations at large. Any successful programs need to be well designed and meet the needs of the participants as well as acknowledging pre-existing skills and attributes. Programs need to be accessible and provide appropriate knowledge to assist an individual to make a fully informed decision. 


\section{References}

Applied Research Consulting 2009, Financial Capability in the United States FINRA Investor, accessed 10 July 2013, http://www.usfinancialcapability.org /downloads/NFCS_2009_Natl_Full_Report.pdf.

Atkinson, A, McKay, S, Kempson, E \& Collard, S 2006, Levels of Financial Capability in the UK: Results of a baseline survey: Financial Services Authority, London, United Kingdom.

Australian Association of Mathematics Teachers 2012, Position paper on Consumer and Financial Literacy in Schools, accessed 9 July 2013, http://www.aamt.edu.au/Publications-and-statements/Position-statements/Consumerand-Financial-Literacy/ (language)/eng-AU.

Australian and New Zealand Bank 2003, ANZ's Adult Financial Literacy Survey, accessed 15/10/2011 http://www.anz.com/aus/aboutanz/Community/Programs/Survey2003.asp.

Australian and New Zealand Bank 2005, ANZ's Adult Financial Literacy Survey, accessed 20/10/2011 http://www.financialliteracy.gov.au/research.

Australian and New Zealand Bank 2008, ANZ Adult Financial Literacy in Australia, Summary Report, accessed 16/06/2010 http://www.anz.com/resources /2/7/273b48804d2fa30f9f34bf766a918285/Financial_Litearcy_Summary_Survey_200 8.pdf.

Australian and New Zealand Bank and Roy Morgan Research 2003, ANZ Survey of Adult Financial Literacy in Australia, accessed 10 July 2013, http://www.thesmithfamily.com.au /webdata /resources/files/ANZreportMay03.pdf.

Australian and New Zealand Bank and Roy Morgan 2011, ANZ Survey of Adult Financial Literacy in Australia, accessed 10 July 2013, http://www.anz.com/resources /f/9/f9fc9800493e8ac695c3d7fc8cff90cd/2011-Adult-Financial-LiteracyFull.pdf.pdf?MOD=AJPERES.

Australian and New Zealand Bank and the Social Research Centre 2008, ANZ Survey of Adult Financial Literacy in Australia, accessed 10 July 2013, http://www.anz.com/resources/5/4/54a7b400413360d8b5d8bda2fd298cdf/SurveyAdult-Financial-Literacy-2008.pdf.

Australian Securities and Investment Commission 2001-2004 Consumer Education Strategy, accessed 09-07-2013, http://www.asic.gov.au/asic/pdflib.nsf/LookupBy FileName/consumer_ed_strategy.pd f/\$file/consumer_ed_strategy.pdf.

Australian Securities and Investment Commission 2003, Summary of stakeholder responses to Financial literacy in schools, Discussion Paper 2003, accessed 20/05/2013 http://www.asic.gov.au/asic/pdflib.nsf/LookupByFileName/Fin_Lit_DP _responses.pdf/ \$file/Fin_Lit_DP_responses.pdf.

Australian Securities and Investment Commission 2010, Financial Literacy and Behavioural Change Report 230, accessed 15-10-2011, http://www.asic.gov.au/asic/pdflib.nsf/ LookupByFileName/rep230-financial-literacy-and-behaviouralchange.pdf/\$file/rep230-financial-literacy-and-behavioural-change.pdf.

Australian Securities and Investment Commission 2011, National financial literacy strategy Report 229, accessed 08-07-2013, http://www.asic.gov.au/asic /pdflib.nsf/LookupByFileName/rep229-national-financial-literacystrategy.pdf/\$file/rep229-national-financial-literacy-strategy.pdf.

Bell, E \& Lerman, RI 2005, 'Can financial literacy enhance asset building? Opportunity and Ownership Project', The Urban Institute, vol.96, pp1-7.

Bernheim, BD, Garrett, DM \& Maki, DM. 2001, 'Education and saving: The long-term effects of high school financial curriculum mandates', Journal of Public Economics, vol.803, pp435-465. http://dx.doi.org/10.1016/S0047-2727(00)00120-1 
Boyce, L \& Danes, SM 2004, Evaluation of the NEFE High School Financial Planning Program, 2003/2004, accessed 20/10/2011 http://nefe.org/ hsfppportal/includes/main/home.asp?portal=4 .

Braunstein, S \& Welch, C 2002, 'Financial literacy: An overview of practice, research, and policy’ Federal Reserve Bulletin, November, pp445-457.

Clancy, M, Grinstein-Weiss, M \& Schreiner, M 2001, 'Financial education and savings outcomes in individual development accounts', Working Paper No. 01/2, Center for Social Development, Washington University, St. Louis, MO.

Citi Bank Australia and The Australian Institute 2010, Evidence Versus Emotion: How Do We Really Make Financial Decisions?, accessed 10 July 2013, http://www. financialliteracy.gov.au/ media/67572/citibank_evidence-versus- emotion.pdf.

Consumer Financial Education Body (CFEB), United Kingdom 2010, Money Guidance Pathfinder - Key Findings and Lessons Learned, accessed 10 July 2013, http://www.google.com.au/search?

De Meza, D, Irlenbusch, B \& Reyniers D 2008, 'Financial capability: A behavioural economics perspective'. Research 69, Financial Services Authority, London School of Economics.

Financial Literacy Foundation 2008, Financial Literacy: Women Understanding Money, accessed 10 July 2013, http://www.financialliteracy.gov.au/media/209296/womenunderstanding- Financial Literacy Foundation and DBM Consultants 2007.

Financial Literacy: Australians Understanding Money, accessed 10 July 2013, http://www. financialliteracy.gov. au/media/209293/australians-understanding-money.pdf money.pdf.

Financial Services Authority, 2006, Financial Capability in the UK: Establishing a Baseline. London. accessed 20 October 2011, http://www.fsa.gov.uk/pubs/ other/fincap_baseline.pdf.

FINRA Investor Education Foundation 2009, 'Financial Capability in the United States', Report on the National Survey Component of the National Financial Capability Study 20/10/2011 accessed http://www.oecd.org/dataoecd/33/14/44279167.pdf

Fox, J, Bartholomae, S \& Lee, J 2005, 'Building the case for financial education', The Journal of Consumer Affairs, vol.391, pp195-214. http://dx.doi.org/10.1111/j.17456606.2005.00009.x

Giskes, R 2005, Financial Literacy in Queensland: Bankruptcy Trends and Government Initiatives. Queensland Parliamentary Library.

Harris Interactive Inc. 2009, Consumer Financial Literacy Survey, accessed 10 July 2013, http://www.nfcc.org/NewsRoom/FinancialLiteracy/files/2009FinancialLiteracySurvey FINAL.pdf.

Harris Interactive Inc. 2011, Consumer Financial Literacy Survey, accessed 10 July 2013, http://www.nfcc.org/newsroom/FinancialLiteracy/files2011/NFCC_2011Financial\%2 0LiteracySurvey_FINALREPORT_033011.pdf.

Hilgert, MA, Hogarth, JM \& Beverly, SG 2003, 'Household financial management: The connection between knowledge and behaviour', Federal Reserve Bulletin, July, pp309-322.

Home School Legal Defense Association (HSLDA) 2013, National Financial Literacy Challenge, accessed 10 July 2013, http://hslda.org/contests/nflc.asp.

Hogarth, JM 2002, 'Financial literacy and family \& consumer sciences', Journal of Family and Consumer Sciences, vol.941, pp14-28. 
Hogarth, JM, Beverly, SG \& Hilgert, M 2003, 'Patterns of financial behaviors: Implications for community educators and policy makers' 2003 Federal Reserve System Community Affairs Research Conference. accessed 20/10/2010 http:// www.federalreserve.gov/communityaffairs/national/CA_Conf_SusCommDev/pdf/hog arthjeanne.pdf .

Jump\$tart Coalition 2011, Survey of Personal Financial Literacy Among Students, accessed 20/10/2011 http://www.jumpstart.org/survey.html.

Kiviat, B 2010, How to Teach Kids About Money, accessed 22 July 2013, http://blogs .cfed.org/cfed_news_clips/2010/01/how-to-teach-kids-about-money.html.

Kozup, J \& Hogarth, J 2008, 'Financial literacy, public policy, and consumers' self/protection-more questions, fewer answer', Journal of Consumer Affairs, vol.422, pp127-136. http://dx.doi.org/10.1111/j.1745-6606.2008.00101.x

Lyons, A, Palmer L, Jayaratne K \& Scherpf, E 2006, 'Are we making the grade? A national overview of financial education and program evaluation', Journal of Consumer Affairs, vol.402, pp208-235. http://dx.doi.org/10.1111/j.1745-6606.2006.00056.x

Lyons, AC 2005, 'Financial education and program evaluation: Challenges and potentials for financial professionals', Journal of Personal Finance, vol.44, pp56-68.

Mandell, L. 2006, Financial literacy: If it's so important, why isn't it improving? Networks Financial Institute Policy Brief 2006/PB/08. 20/10/2011 accessed, http://www.networksfinancialinstitute.org/ Lists/Publication\%20Library /Attachments/30/2006/PB/08_Mandell.pdf.

Mandell, L. 2007, Financial literacy of high school students. In J. Xiao Ed, Handbook of consumer finance research pp. 163-184, NY: Springer Publishing.

Mandell, L. 2008, High school financial literacy. In A. Lusardi Ed, Overcoming the Savings Slump. Chicago: University of Chicago Press.

Mandell, Lewis 2009, "The Impact of Financial Education in High School and College On Financial Literacy and Subsequent Financial Decision Making,” 20/10/2011 accessed www.aeaweb.org/assa/2009/retrieve.php?pdfid=507

Mandell, Lewis 2011, Financial Education: What Have We Learned So Far? Unpublished.

Mandell, L, \& Klein, L. 2007, Motivation and financial literacy. Financial Services Review, $16,105-116$.

Mason, C, and Wilson, R, 2000, "Conceptualising Financial Literacy." Loughborough University Business School Research Series 20007.

Morris, L, 2001, An investigation into the financial knowledge levels of New Zealand senior secondary school students, 20/10/2010 accessed, http://www.enzt.co.nz /pdf/Financial\%20Literacy.pdf.

OECD 2005, Recommendation on Principles and Good Practices for Financial Education and Awareness Directorate for Financial and Enterprise Affairs, 20/10/2011 accessed http://www.oecd.org/dataoecd/7/17/35108560.pdf.

Personal Finance Research 2005, Measuring Financial Capability: An Exploratory Study, Financial Services Authority (FSA), United Kingdom, Report no. 37, accessed 10 July 2013, http://www.fsa.gov.uk/pubs/consumer-research/crpr37.pdf.

Reid, C, 2003, Financial literacy: The teachers' perspective, A presentation by Christine Reid, Accessed 23 July 2013, http://www.asic.gov.au/asic/pdflib.nsf/add907 be1c708f42ca 256aca0007f465/34f311ce00c195f1ca 256d8e00271050 /\$FILE/Christine_Reid_finlit_presentation.pdf. 
Schagen, S. \& Lines, A. 1996, Financial Literacy in Adult Life. A Report to the Nat West Group Charitable Trust. Slough. Berkshire: National Foundation for Educational Research NFER, as cited in ANZ Report on Adult Financial Literacy in Australia 20/10/2004 accessed, http://www.smithfamily.com.au/ documents/ANZreport May03_6B798.pdf.

Staten, M. E, Elliehausen, G, \& Linquist, E. C. 2002, The impact of credit counseling on subsequent borrower credit usage and payment behaviour,Monograph \#36, Washington, DC: Georgetown University, Credit Research Center. 20/10/2010 accessed, from http://www.msb.georgetown. edu/prog/crc/pdf/M36.pdf.

Taylor, S. and Wagland,S, 2011, Financial Literacy: A Review of Government Policy and Initiatives. Australiasian Accounting and Business and Finance. Volume 5, Number 2.

The Australian Association of Mathematics Teachers Inc. 2009, Position paper on Consumer and Financial Literacy in Schools 2009, adopted from the January 2009 meeting of the AAMT Council.

The U.S. Presidents Advisory Council on Financial Literacy 2013, accessed 10 July 2013, http://www.whitehouse.gov/the-press-office/2013/03/29/presidential-proclamationnational-financial-capability-month-2013.

The Consumer and Financial Literacy Taskforce, 2004, accessed 20 October 2011, http://cfltaskforce.treasury.gov.au/content/home.asp.

The Financial Brand 2010, Does ‘Financial Literacy’ work. accessed 20 October 2011, http://thefinancialbrand.com/11235/does/financial/literacy/work/.

The Money Advice Service 2011, accessed 20 October 2011, http://money advice service.org.uk/.

Home School Legal Defense Association (HSLDA) 2013, National Financial Literacy Challenge, accessed 10 July 2013, http://hslda.org/contests/nflc.asp.

Vina G 2010, UK Scraps FSA in biggest bank overhaul since 1997, accessed 23 July 2013, http;//www.bloomberg.com/news/2010-06-16/u-k-scraps-fsa-in-biggest-bankregulation-overhaul-since-1997.html.

Widdowson, D \& Hailwood, K 2007, Financial literacy and its role in promoting a sound financial system, accessed 02/12/09, http://www.rbnz.govt.nz/research/bulletin/2007 _2011/2007jun70_2widdowsonhailwoodFinancial Literacy in New Zealand.

Willis, Lauren E., Against Financial Literacy Education. Iowa Law Review, Vol. 94, 2008; U of Penn Law School, Public Law Research Paper No. 08-10; Loyola-LA Legal Studies Paper No. 2008-13. Available at SSRN: http://ssrn.com/abstract=1105384. 


\section{Appendix A}

Comparative Table of Financial Literacy Surveys and Reports

\begin{tabular}{|c|c|c|}
\hline Australia & United Kingdom & United States \\
\hline $\begin{array}{l}\text { ANZ Survey of Adult Financial } \\
\text { Literacy in Australia } \\
\text { ANZ and Roy Morgan Research } \\
\text { December } 2011\end{array}$ & $\begin{array}{l}\text { Money Guidance Pathfinder - } \\
\text { Key Findings and Lessons } \\
\text { Learned } \\
\text { Consumer Financial Education } \\
\text { Body (CFEB), United Kingdom } \\
\text { July } 2010\end{array}$ & $\begin{array}{l}2011 \text { Consumer Financial } \\
\text { Literacy Survey } \\
\text { Harris Interactive Inc. March } \\
2011\end{array}$ \\
\hline $\begin{array}{l}\text { Financial Literacy and } \\
\text { Behavioural Change } \\
\text { ASIC March } 2011\end{array}$ & $\begin{array}{l}\text { Transforming Financial } \\
\text { Behaviour: Developing } \\
\text { Interventions that Build } \\
\text { Financial Capability } \\
\text { Consumer Financial Education } \\
\text { Body (CFEB), United Kingdom } \\
\text { July } 2010\end{array}$ & $\begin{array}{l}\text { Consumer Financial Literacy } \\
\text { Survey } \\
\text { Harris Interactive Inc. March } \\
2009\end{array}$ \\
\hline $\begin{array}{l}\text { Evidence Versus Emotion: How } \\
\text { Do We Really Make Financial } \\
\text { Decisions? } \\
\text { Citi Bank Australia and The } \\
\text { Australian Institute } \\
\text { December } 2010\end{array}$ & $\begin{array}{l}\text { Financial Capability: A } \\
\text { Behavioural Economics } \\
\text { Perspective } \\
\text { Financial Services Authority, } \\
\text { United Kingdom, July } 2008\end{array}$ & $\begin{array}{l}\text { Financial Capability in the } \\
\text { United States } \\
\text { FINRA Investor } \\
\text { Education Foundation } \\
2009\end{array}$ \\
\hline $\begin{array}{l}\text { ANZ Survey of Adult Financial } \\
\text { Literacy in Australia } \\
\text { ANZ and the Social Research } \\
\text { Centre } \\
\text { October } 2008\end{array}$ & $\begin{array}{l}\text { Levels of Financial Capability } \\
\text { in the UK: Baseline Survey } \\
\text { Prepared for the Financial } \\
\text { Services Authority (FSA), } \\
\text { United Kingdom } \\
\text { March } 2006\end{array}$ & $\begin{array}{l}\text { The U.S. Presidents Advisory } \\
\text { Council on Financial Literacy } \\
\text { seeks to assist the American } \\
\text { people in understanding and } \\
\text { addressing financial matters } \\
\text { through various tools: website, } \\
\text { National Financial Literacy } \\
\text { Challenge (online test for high- } \\
\text { school students), and } \\
\text { MoneyMath: Lessons for Life } \\
\text { curriculum (7-9 grades) }\end{array}$ \\
\hline $\begin{array}{l}\text { Financial Literacy: Women } \\
\text { Understanding Money } \\
\text { Financial Literacy Foundation } \\
\text { April } 2008\end{array}$ & $\begin{array}{l}\text { Measuring Financial } \\
\text { Capability: An Exploratory } \\
\text { Study } \\
\text { Prepared for the Financial } \\
\text { Services Authority (FSA), } \\
\text { United Kingdom, } \\
\text { June } 2005\end{array}$ & \\
\hline \multicolumn{3}{|l|}{$\begin{array}{l}\text { Financial Literacy: Australians } \\
\text { Understanding Money } \\
\text { Financial Literacy Foundation } \\
\text { and DBM Consultants } \\
\text { September } 2007\end{array}$} \\
\hline $\begin{array}{l}\text { ANZ Survey of Adult Financial } \\
\text { Literacy in Australia } \\
\text { ANZ and AC Nielsen } \\
\text { November } 2005 \text { and } 2003\end{array}$ & & \\
\hline
\end{tabular}




\section{Appendix B}

\section{Map of the National Financial Literacy Strategy}

To enhance the financial wellbeing of all Australians by improving financial literacy levels

\section{Underpinning principles}

Inclusiveness - reach all Australians, particularly those most in need and future generations of consumers and investors Engagement-help all Australians appreciate the importance of financial literacy and that small things done regularly make a real difference

Diversity-deliver learning that recognises the different ways people learn and allows all Australians to participate Knowledge and empowerment - give all Australians access to independent and reliable information, tools and ongoing support

Improving outcomes-recognise that information alone is not always enough and use additional mechanisms to achieve better outcomes

Partnerships - map and build on existing foundations to fill gaps and ensure all sectors and agencies work cooperatively Measurement - evaluate our work to know what is and isn't effective, and learn from and share these evaluations

\begin{tabular}{|c|c|c|c|}
\hline \multicolumn{4}{|c|}{ How we will do this } \\
\hline Education & $\begin{array}{c}\text { Information and ongoing } \\
\text { support }\end{array}$ & $\begin{array}{l}\text { Achieving behavioural } \\
\text { change }\end{array}$ & $\begin{array}{c}\text { Coordination and the long } \\
\text { haul }\end{array}$ \\
\hline $\begin{array}{l}\text { Integrate and embed financial } \\
\text { literacy into the Australian } \\
\text { Curriculum }\end{array}$ & $\begin{array}{l}\text { Create a continuum from } \\
\text { engagement, to knowledge, to } \\
\text { skills, to support, to action }\end{array}$ & $\begin{array}{l}\text { Understand why } \\
\text { consumers behave as they } \\
\text { do-learn from behavioural } \\
\text { economists and social } \\
\text { marketing experts }\end{array}$ & $\begin{array}{l}\text { Identify and foster partnerships } \\
\text { with sectors best placed to } \\
\text { design, fund, deliver and } \\
\text { measure initiatives }\end{array}$ \\
\hline $\begin{array}{l}\text { Ensure sustainability of school } \\
\text { programs through strategic } \\
\text { partnerships with education } \\
\text { stakeholders, professional } \\
\text { learning for teachers and } \\
\text { access to high-quality } \\
\text { resources }\end{array}$ & $\begin{array}{l}\text { Understand people's } \\
\text { information needs and learning } \\
\text { preferences and design tools } \\
\text { and materials to match them }\end{array}$ & $\begin{array}{l}\text { Apply this knowledge to the } \\
\text { design of financial literacy } \\
\text { programs }\end{array}$ & $\begin{array}{l}\text { Build on and establish new } \\
\text { mechanisms to improve } \\
\text { coordination, knowledge } \\
\text { sharing and networking }\end{array}$ \\
\hline $\begin{array}{l}\text { Increase the take-up of } \\
\text { financial literacy options in } \\
\text { further education, especially } \\
\text { VET and teacher pre-service } \\
\text { education }\end{array}$ & $\begin{array}{l}\text { Develop a new interactive } \\
\text { ASIC website that equips } \\
\text { people for action and gives } \\
\text { ongoing support }\end{array}$ & $\begin{array}{l}\text { Recognise that more than } \\
\text { educational solutions are } \\
\text { needed if better outcomes are } \\
\text { to be achieved }\end{array}$ & $\begin{array}{l}\text { Contribute to international } \\
\text { work on best-practice } \\
\text { evaluation mechanisms for } \\
\text { financial literacy-including } \\
\text { the OECD’s trial testing of } \\
\text { financial literacy through the } \\
\text { Program for International } \\
\text { Student Assessment (PISA) in } \\
2012\end{array}$ \\
\hline $\begin{array}{l}\text { Expand the take-up of } \\
\text { financial literacy training in } \\
\text { the workplace, especially for } \\
\text { small business }\end{array}$ & $\begin{array}{l}\text { Recognise the ongoing need to } \\
\text { engage with non- web-based } \\
\text { materials }\end{array}$ & $\begin{array}{l}\text { Influence public policy and } \\
\text { product design settings to } \\
\text { maximise outcomes that } \\
\text { promote financial wellbeing }\end{array}$ & $\begin{array}{l}\text { Apply appropriate measures } \\
\text { for each initiative }\end{array}$ \\
\hline $\begin{array}{l}\text { Work with relevant } \\
\text { government agencies, the } \\
\text { community sector and others } \\
\text { to deliver financial literacy } \\
\text { programs to adults, with a } \\
\text { focus on those most in need } \\
\text { and on issues and products } \\
\text { causing the greatest problems }\end{array}$ & $\begin{array}{l}\text { Develop resources } \\
\text { relevant to and designed to } \\
\text { reach people at key } \\
\text { 'teachable moments' }\end{array}$ & $\begin{array}{l}\text { Work with FaHCSIA and } \\
\text { financial counsellors to assist } \\
\text { in the development of an } \\
\text { online diagnostic tool for } \\
\text { people with debt problems }\end{array}$ & $\begin{array}{l}\text { Measure and track overall } \\
\text { Australian financial literacy } \\
\text { rates }\end{array}$ \\
\hline
\end{tabular}




\section{Appendix C}

Financial Literacy Priorities for Schools

\begin{tabular}{|l|l|}
\hline \multicolumn{1}{|c|}{ Priority } & \multicolumn{1}{|c|}{ Timeline } \\
\hline $\begin{array}{l}\text { Ensure financial literacy is explicit in the Australian } \\
\text { Curriculum }\end{array}$ & Short - Medium \\
\hline $\begin{array}{l}\text { Support teacher professional learning aligned to the } \\
\text { Australian Curriculum }\end{array}$ & Short - Medium \\
\hline $\begin{array}{l}\text { Support the development of high quality consumer and } \\
\text { financial literacy resources aligned to the Australian } \\
\text { Curriculum }\end{array}$ & Short - Medium \\
\hline $\begin{array}{l}\text { Support and encourage innovative and sustainable } \\
\text { approaches to consumer and financial literacy } \\
\text { education that will support the reform agenda and } \\
\text { build and evidence base }\end{array}$ & Ongoing \\
\hline $\begin{array}{l}\text { Promote financial literacy to student schools, parents, } \\
\text { professional education associations, education sectors, } \\
\text { business and community, and nuture strategic } \\
\text { partnerships }\end{array}$ & Ongoing \\
\hline $\begin{array}{l}\text { Support financial literacy pilot projects for indigenous } \\
\text { schools and communities }\end{array}$ & Short - Medium \\
\hline $\begin{array}{l}\text { Explore and develop national and international } \\
\text { evaluation processes that will help build the evidence } \\
\text { base for consumer and financial literacy }\end{array}$ & Ongoing \\
\hline
\end{tabular}

Source: ASIC Report 229 
AABFJ | Volume 7, no. 3, 2013 